\title{
Nutritional Substances Affecting the Immune System
}

\author{
Nil Sipahioğlu ${ }^{1, a, *}$, Gültekin Yıldız ${ }^{1, b}$ \\ ${ }^{1}$ Department of Animal Nutrition and Nutritional Disease, Faculty of Veterinary Medicine, Ankara University, 06110 Ankara, Turkey \\ * Corresponding author
}

\begin{tabular}{l|l}
\hline A R T I C L E I N F O & A B S T R A C T \\
\hline Reviewed Article & $\begin{array}{l}\text { There are many nutrients that affect animal health and strengthen immunity. Some of these are } \\
\text { recognized as additives. Ascorbic acid has a very important function in the immune system, in the } \\
\text { synthesis of carnitine and in the use and absorption of other nutrients. } \beta \text {-glucan is a stimulator of the } \\
\text { cardiovascular system and immune system. } \beta \text {-glucan has a stimulating effect on macrophages, } \\
\text { increasing the cytotoxicity and phagocytic capacity of macrophages. It also shows antioxidant, } \\
\text { antiviral, antibacterial, and antifungal activity and has a healing effect on wounds. Inulin is a } \\
\text { prebiotic that is isolated from the roots of chicory and yams and is effective on the immune system. } \\
\text { It has been determined that prebiotics, which are very difficult to digest under normal conditions, are } \\
\text { the food of probiotics. Probiotics affect the immune system with the metabolites they secrete. } \\
\text { Accepted : } 26 / 04 / 2021 \\
\begin{array}{l}\text { Keywords: } \\
\text { Boron } \\
\text { B-glucan } \\
\text { Immune System } \\
\text { Minerals }\end{array}\end{array} \begin{array}{l}\text { havect on immunity. When the minerals required in chemical reactions are at a sufficient level, they } \\
\text { rich deposits in our country, as an additive in animal feeds. }\end{array}$
\end{tabular}

Minerals

Prebiotic

Tavukçuluk Araştırma Dergisi 18(1): 1-4, 2021

\section{Bağışıklık Sistemine Etkili Besin Maddeleri}

\begin{tabular}{|c|c|}
\hline M A K A L E B İ L G İ S İ & Ö Z \\
\hline $\begin{array}{l}\text { Anahtar Kelimeler: } \\
\text { Bor } \\
\text { ß-glukan } \\
\text { İmmün Sistem } \\
\text { Mineraller } \\
\text { Prebiyotik }\end{array}$ & $\begin{array}{l}\text { Hayvan sağlığını etkileyen, bağışıklığı güçlendiren birçok besin maddesi vardır. Bunların bir kısmı } \\
\text { katkı maddesi olarak tanınmaktadır. Askorbik asit immun sistem üzerinde, karnitin sentezinde ve } \\
\text { diğer besin maddelerinin kullanım ve emiliminde çok önemli bir yer tutar. } \beta \text {-glukan kardiyovasküler } \\
\text { sistem ve immun sistem stimülatörüdür. } \beta \text {-glukan, makrofajlar üzerine uyarıcı etkilidir. } \\
\text { Makrofajların sitotoksisitesini ve fagositik kapasitesini arttırır. Ayrıca antioksidan, antiviral, } \\
\text { antibakteriyel ve antifungal aktivite gösterir ve yaralar üzerinde iyileştirici bir etkiye sahiptir. Inü̈lin } \\
\text { hindibağ ve yer elmasının köklerinden izolasyonu yapılmış, bağışılık sistemine etkili prebiyotiktir. } \\
\text { Normal şartlarda sindirimi çok güç olan prebiyotiklerin probiyotiklerin besini olduğu tespit } \\
\text { edilmiştir. Probiyotikler salgıladıkları metabolitleriyle bağış1klık sistemine etki ederler. Bağışılklı } \\
\text { için etkili olan bir diğer konuda aminoasitlerdir. Aminoasitlerin yeterli seviyede olması bağış1klığa } \\
\text { pozitif yönde etkilidir. Kimyasal tepkimelerde gerekli olan mineraller yeterli seviyede olduklarında } \\
\text { bağışıklığ güçlendirici etkiye sahiptir. Ülkemizde zengin yatakları bulunan bor mineralinin de } \\
\text { hayvan yemlerinde katkı maddesi olarak etkileri üzerinde çalışmalar yürütülmektedir. }\end{array}$ \\
\hline
\end{tabular}




\section{Introduction}

The productivity losses that occur during the illness of the animals continue for a while after they recover, and it takes time to reach their previous performance. Meat, milk or egg of medicated animals cannot be used for a certain period of time. The treatment of sick animals causes economic losses. At the same time, there should be separate compartments in the farm to prevent the spread of the disease. It should be easier to strengthen preventive medicine instead of dealing with all these problems. For this, it is necessary to keep the immune system active. In order not to weaken the strength of immunity, a stress-free life and sufficient nutrients should be provided. In cases where routine practices are not sufficient, supplements or additives to be added to the diet come to the fore when high immunity is needed.

\section{Vitamin C}

Ascorbic acid (vitamin C) plays an important role in collagen, carnitine, neurotransmitter biosynthesis (Karabayır and Gökçay, 2006). In animals (except Primates), ascorbic acid can be synthesized from glucose and galactose in the organism by L-gulonolactone oxidase enzyme. In poultry, it can synthesize sufficient amount of ascorbic acid for metabolism in the kidneys under normal conditions. The synthesis of vitamin $\mathrm{C}$ may decrease with the effect of factors that cause stress in poultry, such as disease, vaccination, high temperature and congestion. The most important properties of Vitamin $\mathrm{C}$ are that it has an antioxidant effect (Yarsan and Güleç, 2003).

Vitamin $\mathrm{C}$ is a powerful water-soluble antioxidant. It contributes to the preservation of the structure of vitamins E, A and B and to fulfill their functions. It neutralizes the negative effects of heavy metals such as lead, mercury and arsenic and strengthens the immune system (Levine, 1986).

Vitamin C increases the leukocyte activity, interferon level and effect, antibody number and response in the immune system. In addition, it has an effective role in the production of hormones and transmitters in the nervous tissue, the synthesis of carnitine, and the absorption and use of nutrients (Synlab, 2018).

Sizmaz and Yildiz (2014) reported that, dietary addition of ascorbic acid (200 mg / kg) significantly increased the feed conversion ratio and egg yield and decreased serum cholesterol level.

\section{Inulin}

Inulin is usually found in roots and stems and is used by many plants to store energy. They are fermented in the large intestine through the microflora and support the healthy growth of microorganisms in the microflora (Srinivasjois and Patole, 2009). The main sources of inulin are chicory and Jerusalem artichoke. Purified inulin can be obtained from berry or chicory tubers (Niness, 1999). Chicory roots contain glucose, fructose and sucrose (6-10\% sugar) (Sabater-Molina et al., 2009). 3-2,1- linkages determine the specific properties of inulin, protecting it against digestion in the upper part of the gastrointestinal tract (Niittynen et al., 2007). Inulin has been found to increase the cytotoxicity of NK cells (natural killer immune cells). Inulin has stimulating properties on the immune response against carcinogenic agents (Watzl et al., 2005).

It has been determined that inulin originating from jerusalem artichoke provides improvement in feed utilization and egg production in laying hens and improves house environment (Y1ldiz et al., 2008).

\section{B-Glukan}

ß-glucans are non-starch polysaccharides found in grain feeds. Glucans are formed by the combination of many glucose molecules in different conformations. The ß-glucan used in animal nutrition is isolated from natural sources. Yeast (Saccharomyces cerevisiae), fungus, seaweed, and bacteria are used to obtain biologically active glucan. Oat grain is also a good source (Vetvicka, 2003). Polysaccharides have been shown to stimulate the immune system. Literature reports show that beta-glucans show antioxidant, antiviral, antibacterial, and antifungal activities and have a healing effect on wounds (Chen and Seviour, 2007; Wei et al., 2002).

Studies have shown that $\beta$-glucan can activate cells belonging to the innate nonspecific immune system. Thanks to this effect, animals that consume $\beta$-glucan can more easily fight viruses, bacterial infections, fungal and parasitic infections (Engstad and Robertsen, 1994).

The advantage of $\beta$-glucan in the body defense system is that it binds to specific receptors on different cell types in the first step. In this way, glucans are particularly effective in macrophage stimulation (Vetvicka, 2003). Glucans have macrophage and nonspecific tumordestroying activation (Mansell, 1986). The presence of glucan affects the bone marrow, affects the proliferation of substances that stimulate and activates the general immune system, and plays a role in the release of more cytokines. Malnutrition, long-term infections, advancing age create individual differences in immune system stimulation. In order to eliminate this individual difference in immune system stimulation, $\beta$-glucan can be used to activate the immune system in cancer, delayed wound healing, arthritis, and in cases where the risk of fungal, bacterial and viral infection increases. Likewise, it can be used in cases where the marrow within the bone needs to be stimulated due to the decrease in the number of white and red blood cells (Price and Makinodan, 1972).

The broad anti-infective benefit of B-glucan is explained by its immunostimulant properties. The use of B-glucan reduces the amount of antibiotic or antiviral substance use in bacterial diseases such as Staphylococcus aureus, Klebsiella pneumoniae, Escherichia coli, when given in addition to antibiotic treatment in animals affected by Herpes virus. The antifungal effect of $\beta$-glucan has been observed especially against Candida albicans (Wyde, 1989).

Significant increase in colostrum IgG level was formed as a result of 1,3 / 1,6 $\beta$-glucan administration to pregnant mares and foals (Krakowski et al., 1999). The positive effects of the use of $\beta$-glucan in broilers (Cheng et al., 2004) and the combination of $\beta$-glucan and inulin were observed (Elrayeh and Y1ld1z, 2012). 


\section{Minerals}

Trace minerals; They play a very important role in normal growth and many metabolic events. Many trace minerals are involved in immune system functions. Positive effects are observed in the presence of trace minerals, especially $\mathrm{Zn}, \mathrm{Cu}$ and $\mathrm{Se}$, in the ration, especially under stress conditions. It is important that trace minerals in farm animals are of inorganic and organic origin. It is understood that organic forms have higher bioavailability and are more effective on the immune system (Saçaklı, 2019).

Boron; It is an essential element for humans, animals and plants. It has been reported that boron is involved in immune function and increases interleukin- 6 production in mammalian macrophages. On the other hand, it has been stated that cholesterol and triglyceride levels decrease, lipid peroxidation decreases, antioxidant effective enzymes increase the endurance, improves mineral substance balance, and increases the synthesis of some steroid hormones (Yıldız and Abacıoglu, 2007). boron has improved feed consumption (Yeşilbağ and Eren, 2008) and improved the level of damaged eggs (Kurtoğlu et al., 2002).

\section{Valin}

Limiting amino acids in broiler diets are lysine, methionine, tryptophan. Threonine has been included in the limited amino acid list in recent years. Valine is an amino acid that has not been sufficiently studied. Thornton et al. (2006) studied the effect of different valine concentrations on the immune system in the second period, and studied different valine uses between the 21 st and 42 nd days. In his studies, different valinates in the second period increased lymphoid organ development. Bhargava et al. (1971) mentioned that antibody titers increased with the increase in the valine level. Kaplan and Y1ldiz (2017) reached a high thymus weight level with $0.1 \%$ and $0.2 \%$ additional valine amounts in their study, valine incorporation increased the development of the thymus and relative organ weight. It is thought that it is appropriate to have a valine ratio of $1 \%$ in the first period feeding in broiler chickens and $0.82 \%$ in the second period ration.

\section{Essential Oils}

Many studies have shown that the active components of essential oils obtained by distillation from plants have bacteriostatic, bactericidal and fungicidal properties. Essential oils have shown successful results in the control of pathogenic microorganisms, their use as antioxidants, stimulation of digestive enzymes activity and nitrogen absorption, reducing environmental pollution caused by fertilizers, and extending the shelf life of foods. Essential oils and extracts obtained from medicinal and aromatic plants improve the growth performance, utilization of the feed, the flavor of the feed, have a stimulating effect on the efficiency of pancreatic enzymes and bile secretion, accelerate the regeneration of epithelial cells in the small intestine and increase the absorption of nutrients by establishing the microflora balance, and prevent the adhesion of harmful microorganisms to intestinal epithelial cells. It is reported that it prevents them from settling in the system and gives strength to the immune system (Karasu and Öztürk, 2014; Khalafalla, 2009; Tonsy et al., 2011; Turan et al., 2012). Jamroz and Kamel (2002) stated that essential oils also improve the fat digestion in broilers. Kitandu et al. (2006) revealed that herbal extracts have anticoccidial properties. It is known that herbal extracts reduce the lesion score (Saini et al., 2004), have antimicrobial (Lee et al., 2004), anti-inflammatory, and immunomodulatory effects on microorganisms (Vieira et al., 2008).

It has been observed that the synergistic effect created by the use of vegetable oil and extracts together has a significant improvement effect on mortality and intestinal health (mixture of thyme oil and black seed oil) (Aydın and Y1ld1z, 2020).

\section{Result}

It is extremely important to keep immunity high, when the importance of immunity is better understood. Many substances that can be taken orally can play a role in enhancing immunity. Vitamin $\mathrm{C}$, inulin, $\beta$-glucan, boron, valine and essential oils that added to animal feeds or foods at certain levels will contribute to strengthening the immune system.

\section{References}

Aydin, Ö.D., Yıldiz, G., 2020. The Effects of Thyme Oil and Black Cumin Oil in Broiler Feeding On Growth Performance, Intestinal Histomorphology, And Cecal Volatile Fatty Acids. Turk J Vet Anim Sci., 44: 17-25.

Bhargava, K.K., Hanson, R.P., Sunde, M.L., 1971. Effects of Methionine and Valine On Growth and Antibody Production in Chicks Infected with Live or Killed Newcastle Disease Virus. Poult. Sci., 50:614-619.

Chen, J., Seviour, R., 2007. Medicinal Importance of Fungal B(1 >3), (1>6)-Glucans. Mycol Res., 111:635-52.

Cheng, Y.H., Lee, D.N., Wen, C.M., Weng, C.F., 2004. Effects of B-Glucan Supplementation on Lymphocyte Proliferation, Macrophage Chemotaxis and Specific Immune Responses in Broilers. Asian Austral. J. Anim., 17: 1145-1149.

Elrayeh, A.S., Yildiz, G., 2012. Effects of Inulin and B-Glucan Supplementation in Broiler Diets on Growth Performance, Serum Cholesterol, Intestinal Length, And Immune System. Turk. J. Vet. Anim. Sci., 36(4): 388-394

Engstad, R.E., Robertsen, B., 1994. Specificity of A ß-Glucan Receptor On Macrophages from Atlantic Salmon (Salmo Salar L.). Developmental Comparative Immunol., 18: 397-408.

Amroz, D., Kamel, C., 2002. Plant Extracts Enhance Broiler Performance. In Non-Ruminant Nutrition: Antimicrobial Agents and Plant Extracts On Immunity, Healt and Performance. J. Anim. Sci., 80 (E.Suppl 1), 41.

Kaplan, M., Y1ldiz, G., 2017. The Effects of Dietary Supplementation Levels of Valineon Performance and Immune System of Broiler Chickens Journal of Agricultural and Crop Research, 5:25-31.

Karabayir, N., Gökçay, G., 2006. Vitamin C. Türkiye Klinikleri J Pediatr Sci., 2:37-41.

Karasu, K., Öztürk, E., 2014. Tibbi Ve Aromatik Bitkilerin Kanatlilarda Antioksidan ve Antimikrobiyal Etkileri. Turkish Journal of Agricultural and Natural Sciences, Special Issue, 2:1766-1772

Khalafalla, M.M.E., 2009. Utilization of Some Med Oreochromis Niloticus Ical Plants as Feed Additives for Nile Tilapia, Oreochromis Niloticus, Feeds. Mediterranean Aquaculture Journal, 2(1): 9-18. 
Kitandu, A., Juranova, R., 2006. Progress in Control Measures for Chicken Coccidiosis. Actavet Brno, 265-276.

Krakowski, L., Krzyzannowski, J., Wrona, Z., Siwicki, A.K., 1999. The Effect of Nonspecific Immunositimulation of Pregnant Mares with 1,3/1,6 Glucan and Levamisol on The Immunoglobulins Levels in Collostrum, Selected Incidences of Nonspecific Cellular and Humoral Immunity in Foals in Neonatal and Postnatal Period. Vet. Immunol. And Immunopathol., 68:1-11.

Kurtoğlu, V., Kurtoğlu, F., Coşkun, B., Şeker, E., Balevi, T., Cetingül, I.S., 2002. Effects of Boron Supplementation On Performance and Some Serum Biochemical Parameters in Laying Hens. Rev. Med. Vet. - Toulous, 153: 823-828.

Lee, K-W., Everts, H., Beynen, A.C., 2004. Essential Oils in Broiler Nutrition. Int. J. Poultry Sci., 3(12): 738-752.

Levine, M., 1986. New Concepts in The Biology and Biochemistry of Ascorbic Acid. N. Eng. J. Med., 3:892-902.

Mansell, P.W.A., 1986. Employment of Soluble Glucan in The Treatment of Patients with Acquired Immunodeficiency Syndrome. M.D Anderson Cancer Center, Ind., 1986.

Niittynen, L., Kajander, K., Korpela, R. 2007. GalactoOligosaccharides and Bowel Function. Scand J Food Nutr., $51: 62$

Niness, K.R., 1999. Inulin and Oligofructose: What Are They? J. Nutr., 129: 1402-1406.

Price, G.B., Makinodan, T., 1972. Immunologic Deficiencies in Senescence. The Journal of Immunology, 108:403-412.

Sabater-Molina, M., Larque, E., Torrella, F., Zamora, S., 2009. Dietary Fructooligosaccharides and Potential Benefits On Health. J Physiol Biochem., 65:315-328.

Saçakli, P., 2019. Mineraller Ve Bağış̧ıklık Ilişkisi. Demirel G (Ed), Hayvanlarda Beslenme Ve Bağışıklık Ilişkisi. 1. Baskı. Ankara: Türkiye Klinikleri, 35-41.

Saini, R., Davis, S., Dudley- Cash, W., 2004. Oregano Essential Oil Reduces the Expression of Coccidiosis in Broiler. 22. World Poultry Congress Book of Abstracts. S: 583.

Sizmaz, O., Yildiz, G., 2014. Effects of Single or Combined Dietary Supplementation of Boric Acid and Ascorbic Acid On Growth Performance, Bone Mineralization and Cholesterolemia in Broilers. Inter J Agri Biosci., 3(5): 214218.

Srinivasjois, R., Rao, S., Patole, S., 2009. Prebiotic Supplementation of Formula in Preterm Neonates: A Systematic Review and Meta-Analysis of Randomized Controlled Trials. Clin Nutr., 28:237-242.
Synlab, 2018. C Vitamini. Erișim Adresi: Https://Www.Synlab.Com.Tr/ Fileadmin/Standortseiten/Synlab_Tr/Pdf/Synlab Vitamin C Askorbik Asit. Pdf Erişim Tarihi: 20.08.2020.

Thornton, S.A., Corzo, G.T., Pharr, W.A., Dozier, Iii, Miles, D.M., Kidd, M.T., 2006. Valine Requirements for Immune and Growth Responses in Broilers from 3 To 6 Weeks of Age. Br. Poult. Sci., 47:190-199.

Tonsy, H.D., Mahmoud, S.H., Labib, E.H., Zaki, M.A., 2011. Effect of Some Medicinal Plants Diets on The Mono-Sex Nile Tilapia (Oreochromis Niloticus), Growth Performance, Feed Utilization and Some Physiological Parameters. Egypt J. Aquat. Biol. \& Fish., 15(2): 53-72.

Turan F, Gürağaç R, Sayin S. 2012. Su Ürünleri Yetiştiriciliğinde Esansiyel Yağlar. Türk Bilimsel Derlemeler Dergisi, 5(1): 35-40.

Vetvicka, V., 2003. Beta Glukan. Immuneks Toplantı Programı. Atatürk Kültür Merkezi, Izmir.

Vieira, S.L., Berres, J., Reis, R.N., Oyarzabal, O.A., Coneglian, J.L.B., Freitas, D.M., Pena, J.E.M., Torres, C.A., 2008. Studies with Sanguinarine Like Alkaloids as Feed Additive in Broiler Diets. Brazilian Journal of Poultry Science, 10: 67-71.

Watzl, B., Girrbach, S., Roller, M., 2005. Inulin, Oligofructose and Immunomodulation. Brit. J. Nutr. 93: 49-55.

Wei, D., Zhang, L., Williams, D.L., Browder, I.W., 2002. Glucan Stimulates Human Dermal Fibroblast Collagen Biosynthesis Through a Nuclear Factor-1 Dependent Mechanism. Wound Repair Regen; 10: 161-168.

Wyde, P., 1989. Nsc-24TM: Research Report On Oral and Intraperitoneal Applications in Mice. Immudyne, Inc.

Yarsan, E., Güleç, M., 2003. Kanatlılarda Stres, Vitamin Ve Mineral Uygulamaları. Türk Veteriner Hekimleri Birliği Dergisi. 55-63.

Yeşilbağ, D., Eren, M., 2008. Yaşlı Yumurta Tavuğu Rasyonlarında Borik Asit Kullanımı. 2. Ulusal Bor Çalıştayı Bildirileri Kitab1, 17-18 Nisan 2008, Ankara. 613-618.

Yıldız, G., Abacioğlu, Ö., 2007. Sağlık Ve Hayvan Besleme Açısından Bor. Iv. Ulusal Hayvan Besleme Kongresi, 24-28 Haziran 2007, Bursa. 481-487.

Yıldız, Y., Sacakli, P., Güngör, T. 2006. The Effect of Dietary Jerusalem Artichoke (Helianthus Tuberosus L.) On Performance, Egg Quality Characteristics and Egg Cholesterol Content in Laying Hens. Czech J. Anim. Sci., 51(8): 349-354. 